\title{
Efficient Air Desulfurization Catalysts Derived from Pig Manure Liquefaction Char
}

\author{
Rajiv Wallace ${ }^{1}$, Sundaramurthy Suresh ${ }^{1,+}$, Elham H. Fini ${ }^{2}$ and Teresa J. Bandosz ${ }^{1, *}$ \\ 1 Department of Chemistry and Biochemistry, The City College of New York, New York, NY 10031, USA; \\ rwallac00@citymail.cuny.edu (R.W.); sureshpecchem@gmail.com (S.S.) \\ 2 Department of Civil, Architectural and Environmental Engineering, North Carolina A\&T State University, \\ 1601 E. Market St., Greensboro, NC 27411, USA; elifini@gmail.com \\ * Correspondence: tbandosz@ccny.cuny.edu; Tel.: +1-212-650-6017 \\ + On leave from Department of Chemical Engineering, Maulana Azad National Institute of Technology \\ Bhopal, Bhopal 462 003, India.
}

Received: 24 October 2017; Accepted: 17 November 2017; Published: 20 November 2017

\begin{abstract}
Biochar from the liquefaction of pig manure was used as a precursor of $\mathrm{H}_{2} \mathrm{~S}$ desulfurization adsorbents. In its inorganic matter, it contains marked quantities of calcium, magnesium and iron, which are known as hydrogen sulfide oxidation catalysts. The char was used either as-received or mixed with $10 \%$ nanographite. The latter was added to increase both the content of the carbon phase and conductivity. $\mathrm{ZnCl}_{2}$ in two different ratios of char to an activation agent (1:1 and 1:2) was used to create the porosity in the carbon phase. The content of the later was between $18-45 \%$. The activated samples adsorbed $144 \mathrm{mg} / \mathrm{g} \mathrm{H}_{2} \mathrm{~S}$. Sulfur was the predominant product of reactive adsorption. Its deposition in the pore system and blockage of the most active pores ceased the materials' activity. The presence of the catalytic phase was necessary but not sufficient to guarantee good performance. The developed porosity, which can store oxidation products in the resulting composite, is essential for the good performance of the desulfurization process. The surface of the composite with nanographite showed the highest catalytic activity, similar to that of the commercial Midas ${ }^{\circledR}$ carbon catalyst. The results obtained indicate that a high quality reactive adsorbent/catalyst for $\mathrm{H}_{2} \mathrm{~S}$ removal can be obtained from pig manure liquefaction wastes.
\end{abstract}

Keywords: pig manure; chemical activation; hydrogen sulfide removal; surface chemistry; porosity

\section{Introduction}

Waste remediation and toxic gas containment are among the problems which have to be addressed by a contemporary society. Many hazardous gases such as hydrogen sulfide $\left(\mathrm{H}_{2} \mathrm{~S}\right)$ continue to be emitted by industrial plants, further compounding already existing environmental problems $[1,2]$. $\mathrm{H}_{2} \mathrm{~S}$ affects various organ systems [3,4]. Its effects on the body can rapidly lead to death when exposed to high concentrations (over $1000 \mathrm{mg} / \mathrm{m}^{3}$ ) [5]. The above concerns have prompted environmental agencies to issue drastic exposure limits, and stimulated research to decrease the exposure to this gas. Hydrogen sulfide is one of the most common compounds found in petrochemical processing plants, the feedstock of syngas, and wastewater treatment plants. The efficient removal of $\mathrm{H}_{2} \mathrm{~S}$ has been a major issue in industrial processes. Among the various sulfur removal techniques, adsorption on carbon-based materials at an ambient temperature and pressure has been found to be economical and cost-effective for medium and small-scale sulfur removal units [6-9].

In recent years, the novel idea of using biomass waste as a source of adsorbents of toxic gases and various liquids has been developed and research in this area is ongoing [10-13]. The term biochar has been used to refer to these increasingly popular and cost-effective materials. Biochar is the carbon-rich product of the thermal decomposition of organic matter in an inert atmosphere. 
Even though biochar and activated carbon (AC) have many similarities, they differ primarily in their preparation method, precursor material, and the resulting physical and chemical properties of the final products. With biomass waste being the feedstock, biochar becomes more energy-efficient and less cost-intensive than commercial activated carbons. In some cases, it can be an alternative adsorbent [14-16].

Various chemical activation agents, such as $\mathrm{K}_{2} \mathrm{CO}_{3}$ [17], $\mathrm{H}_{2} \mathrm{SO}_{4}$ [18], $\mathrm{H}_{3} \mathrm{PO}_{4}$ [19], and $\mathrm{ZnCl}_{2}$ [20], have been used to alter the physical properties of industrial waste-based adsorbents in order to increase their performance and to make it comparable to that of commercial grade carbons. Of course, all these methods add costs and make the competition with activated carbon less favorable.

Various municipal [21-23] and industrial [24-26] as well as animal manure [27-29] wastes have been used to produce adsorbents. Simple carbonization does not lead to an extensive surface area owing to a limited content of an organic matter and a high content of inorganic compounds, mainly in the sludges $[30,31]$. The highest area among the adsorbents obtained from sewage sludge was reported be $137 \mathrm{~m}^{2} / \mathrm{g}$ [32]. It is well known that chemical activation by $\mathrm{ZnCl}_{2}$ or $\mathrm{H}_{2} \mathrm{SO}_{4}$ increases the surface area of the manure-based adsorbents to as high as $555 \mathrm{~m}^{2} / \mathrm{g}[32,33]$. Still, owing to the low content of an organic matter, there are limits to the porosity development in the sludge-based adsorbents. Nevertheless, some inorganic matter might bring important catalytic properties [34].

Due to its high organic content, animal manure seems to be an attractive precursor to develop adsorbents. It was reported that such materials can have similar pore structure parameters to those of activated carbon [35,36] and also alkaline surface chemistry [37]. These features make them suitable for adsorptive separations. Lima et al. [38] studied adsorbents derived from turkey litter and reported a maximum surface area of $472 \mathrm{~m}^{2} / \mathrm{g}$ and an adsorption capacity of $1.86 \mathrm{mmol}$ $\mathrm{Cu}^{2+} / \mathrm{g}$ carbon. This capacity was superior to those obtained on two commercial carbons studied: Minotaur $^{\circledR}\left(0.93 \mathrm{mmol} \mathrm{Cu}^{2+} / \mathrm{g}\right.$ carbon) and PUR $\mathrm{RF}^{\circledR}\left(0.28 \mathrm{mmol} \mathrm{Cu}^{2+} / \mathrm{g}\right.$ carbon $)$. It is important to mention that both commercial carbons' surface areas were much higher than that of the turkey-litter-derived materials. (Minotaur ${ }^{\circledR}-844 \mathrm{~m}^{2} / \mathrm{g}$; PUR $\mathrm{RF}^{\circledR}-511 \mathrm{~m}^{2} / \mathrm{g}$ ). The development of adsorbents with manure as a precursor also presents added benefits such as an agricultural sustainability and land restoration [39]. Additionally, the pyrolysis process, since it degrades bacteria and pathogens, also provides the added benefit of reducing environmental health effects [40,41].

$\mathrm{Xu}$ et al. [10] have explored the use of manure as a precursor of adsorbents of hydrogen sulfide. Their results showed that manure-derived biochars were more efficient than were those sewage-sludge-based adsorbents. Tests were conducted in moist conditions and the reported capacities were $47.5 \mathrm{mg} / \mathrm{g}$ for pyrolized sewage sludge and $65.4 \mathrm{mg} / \mathrm{g}$ for pig-manure-based chars. The superior performance of the latter was due to the higher surface basicity. Strong alkalinity and a rich inorganic content in both chars played a crucial role in the $\mathrm{H}_{2} \mathrm{~S}$ uptake as well as in the catalytic formation of elemental sulfur and $\mathrm{SO}_{4}{ }^{2-}$. The latter was formed on the surface, whereas the former was formed in the pores of the material. This was attributed to more $\mathrm{O}_{2}$ present on the outer surface, which oxidized $\mathrm{H}_{2} \mathrm{~S}$ to $\mathrm{SO}_{4}{ }^{2-}$, as opposed to limited $\mathrm{O}_{2}$ in the pores, which resulted in an incomplete oxidation of $\mathrm{H}_{2} \mathrm{~S}$ to elemental sulfur. On the pyrolized sewage sludge, $\mathrm{SO}_{4}{ }^{2-}$ likely combined with $\mathrm{Ca}$, forming an insoluble anhydride, whereas on pig manure char it was in the form of soluble $\mathrm{SO}_{4}{ }^{2-}$.

In this work, composites were synthesized from a manure-derived carbonaceous material similar to biochar but not as carbon-rich. The char is a waste from a pig manure liquefaction process leading to bioresins [42]. The physical properties were modified using a zinc chloride $\left(\mathrm{ZnCl}_{2}\right)$ activation and the addition of nanographite (NG). While the former was intended to increase the porosity, the latter was added to increase the carbon phase content and conductivity. The performance of the synthesized materials as adsorbents of $\mathrm{H}_{2} \mathrm{~S}$ at ambient conditions was investigated. To understand the adsorption performance and to link it to surface features, various characterization techniques such as nitrogen adsorption measurements, thermogravimetric analysis, elemental analysis, and X-ray diffraction were employed. 


\section{Results and Discussion}

Hydrogen sulfide breakthrough curves are shown in Figure 1 and the calculated breakthrough capacities and surface $\mathrm{pH}$ values are collected in Table 1. The breakthrough curves for all samples are relatively steep, indicating fast adsorption kinetics. Pyrolysis alone has little effect on the performance of the manure-derived composites. On the other hand, chemical activation and/or the addition of the NG phase, significantly increase the breakthrough time. The $\mathrm{SO}_{2}$ release data is shown in Figure 2. Concentrations as high as 0.3 ppm were detected for BM, AB, ABA-1, ABA-NG and ABA-NG2 (the names of the samples are defined in Sections 3.1 and 3.2). Lower maximum concentrations were detected for ABA-1 (0.2 ppm) and ABA-NG1 $(0.1 \mathrm{ppm})$. This finding highlights the ability of the materials to catalyze the formation of $\mathrm{SO}_{2}$ and also potentially retain the gas on their surfaces. For all experiments, once the inlet gas was closed (after 100 ppm $\mathrm{H}_{2} \mathrm{~S}$ ) and the system was purged with moist air, all sensor readings returned to zero within one minute.

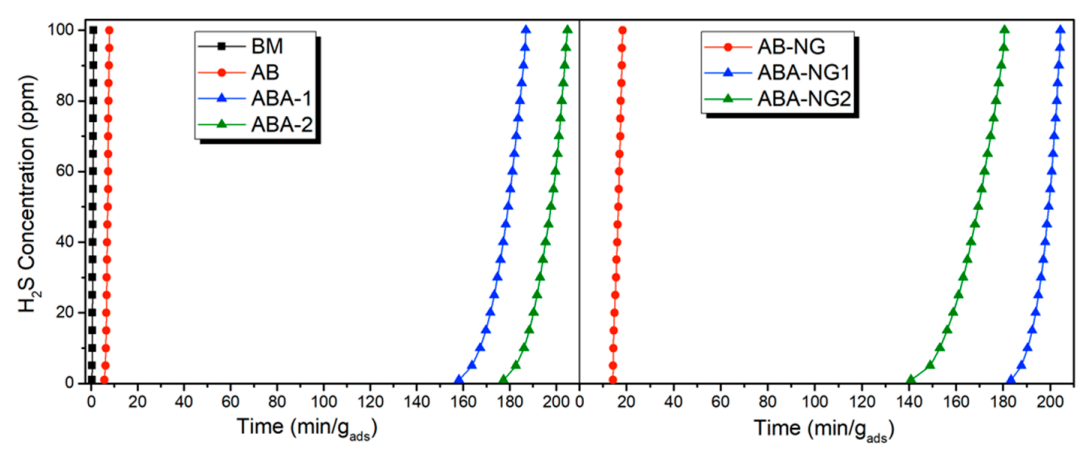

Figure 1. $\mathrm{H}_{2} \mathrm{~S}$ breakthrough curves for manure-derived samples in moist conditions.

Table 1. $\mathrm{H}_{2} \mathrm{~S}$ breakthrough capacities, surface $\mathrm{pH}$ and carbon content for initial and exhausted samples.

\begin{tabular}{|c|c|c|c|c|}
\hline Sample & Ash Content (\%) & $\mathrm{pH}$ & $\mathrm{H}_{2} \mathrm{~S}$ Breakthrough Capacity (mg/g) & Water Uptake (mg $\mathrm{H}_{2} \mathrm{O} / \mathrm{g}$ ) \\
\hline $\mathrm{BM}$ & 59 & 8.10 & 1 & 11 \\
\hline BM-E & - & 7.90 & - & - \\
\hline $\mathrm{AB}$ & 82 & 10.02 & 6 & 18 \\
\hline AB-E & - & 8.32 & - & - \\
\hline ABA-1 & 70 & 6.42 & 132 & 137 \\
\hline ABA-1-E & - & 4.32 & - & - \\
\hline ABA-2 & 66 & 7.30 & 144 & 150 \\
\hline ABA-2-E & - & 5.77 & - & - \\
\hline AB-NG & 70 & 9.16 & 13 & 44 \\
\hline AB-NG-E & - & 8.47 & - & - \\
\hline ABA-NG1 & 62 & 6.91 & 144 & 98 \\
\hline ABA-NG1-E & - & 3.63 & - & - \\
\hline ABA-NG2 & 55 & 7.05 & 127 & 92 \\
\hline ABA-NG2-E & - & 5.58 & - & - \\
\hline
\end{tabular}

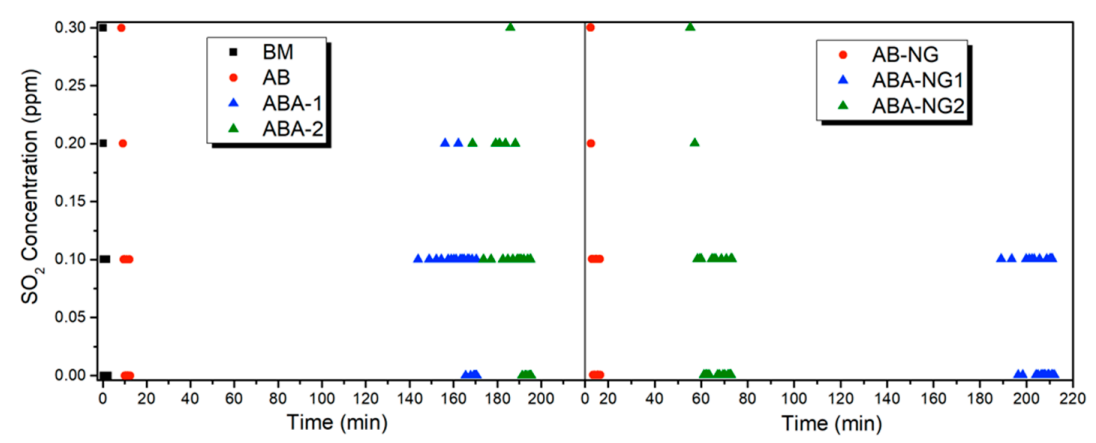

Figure 2. The concentration of $\mathrm{SO}_{2}$ released from the manure-derived samples during $\mathrm{H}_{2} \mathrm{~S}$ breakthrough experiments in moist conditions. 
Among the samples derived from only manure char (AB, ABA-1 and ABA-2) the best performance was found for ABA-2, on which $144 \mathrm{mg}$ of $\mathrm{H}_{2} \mathrm{~S}$ per gram of adsorbent was retained. The addition of nanographite improved the performance slightly, which might suggest that features other than the carbon content (it increased about $10 \%$ ) govern the uptake of $\mathrm{H}_{2} \mathrm{~S}$. Though AB-NG showed a $100 \%$ increase in the performance compared to that of $\mathrm{AB}$, the results for ABA-NG1 and ABA-NG2 were very similar to those obtained for ABA-1 and ABA-2. What is interesting here is that unlike for the samples without NG, the adsorption capacity on ABA-NG2 was about 10\% smaller than that on ABA-NG1.

The best performing samples also have a high affinity to adsorb water. As indicated elsewhere, water is important to create a film in the pore structure in which hydrogen sulfide can dissociate in alkaline environment [43]. $\mathrm{HS}^{-}$then undergoes the oxidation process to sulfur or $\mathrm{SO}_{2} / \mathrm{SO}_{3}$.

In all cases, $\mathrm{ZnCl}_{2}$ activation significantly improved the performance of manure-based bio-char. However, the values reported are not superior to some of those previously reported in the literature for catalytic commercial-activated carbons on which even $60 \mathrm{wt} \%$ of sulfur can be adsorbed [43]. Nevertheless, it is important to mention that the values are much higher than those measured under similar conditions on virgin activated carbons [43] and comparable to those on Centaur ${ }^{\circledR}$ or caustic impregnated carbons [44]. This in turn, indicates the potential merits of tailoring the properties of bio-char for applications other than soil enrichment.

To explain the good performance of the newly developed manure biochar-derived adsorbents, their surface was characterized in detail from the point of view of both porosity and chemistry. From the measured nitrogen adsorption isotherms (Figure 3), the parameters of the pore structure (Table 2) and pore size distributions were calculated (Figure 4).

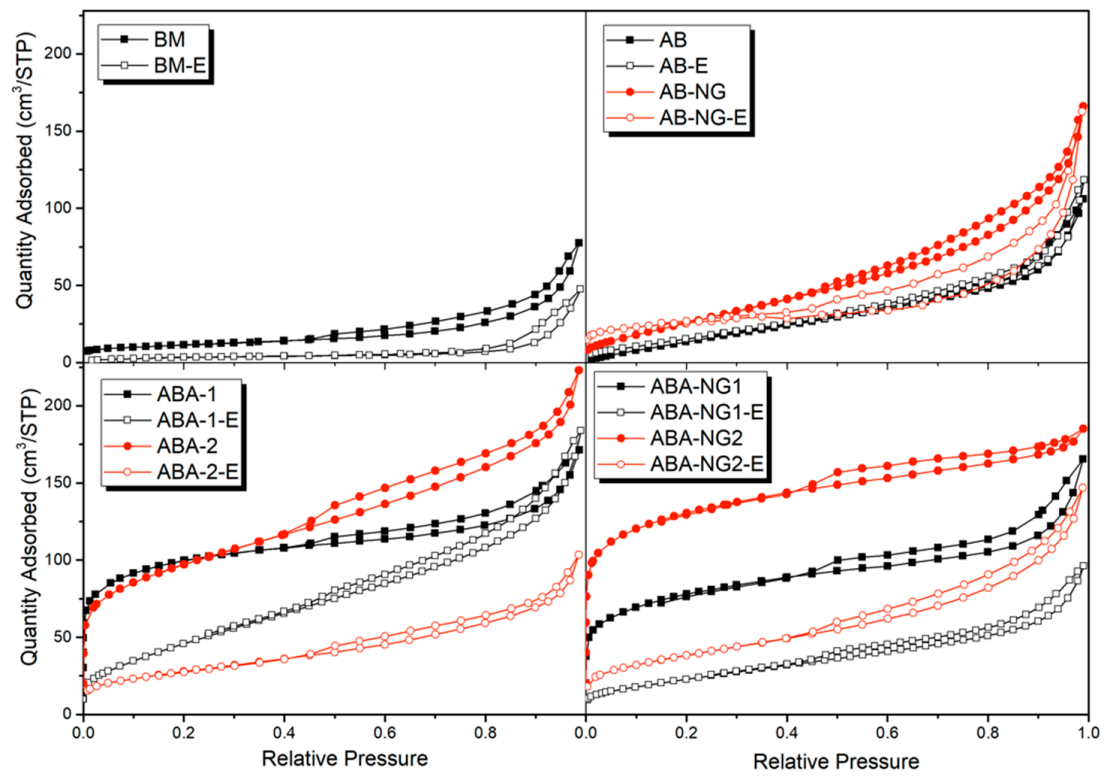

Figure 3. Nitrogen adsorption isotherms for the initial and exhausted samples.

The pyrolysis of the initial waste char resulted in an $80 \%(72 \mathrm{mg} / \mathrm{g})$ increase in the surface area; the addition of nanographite further increased the surface area by $45 \%$ to $105 \mathrm{mg} / \mathrm{g}$. Activation with $\mathrm{ZnCl}_{2}$ resulted in surface areas between 250 and $330 \mathrm{~m}^{2} / \mathrm{g}$. The surface areas for ABA- 1 and ABA-2 increased to $319 \mathrm{~m}^{2} / \mathrm{g}$ and $331 \mathrm{~m}^{2} / \mathrm{g}$, respectively. The similar surface area of ABA-1 and ABA-2 indicate that an increase in the amount of $\mathrm{ZnCl}_{2}$ does not significantly affect the porosity. In fact, only a slight increase in the volume of micropores was found for ABA-2 in comparison with that of ABA-1. This might be related to the limited amount of the carbon phase, which undergoes the activation process. Nevertheless, as seen from Table 1, the carbon content in ABA- 2 is about $10 \%$ higher than that in ABA-1. It should be noted that even though the addition of NG increases the carbon 
content of ABA by $10 \%$, it does not lead to the same increase in the porosity. In fact, the surface area of BA-NG1 decreased about $24 \%$ in comparison to that of ABA-NG2. Interestingly, the pore volumes remain almost the same with or without NG, suggesting that nonporous NG does not undergo any chemical activation. On the other hand, a higher amount of activation agent results in apparently similar porosity to that of ABA-2, suggesting a higher extent of activation than that in ABA-NG1.

Table 2. Pore-structure parameters calculated by nitrogen adsorption isotherms.

\begin{tabular}{cccccc}
\hline Sample & $\mathbf{S}_{\text {BET }}\left(\mathbf{m}^{2} / \mathbf{g}\right)$ & $\mathbf{V}_{\mathbf{T}}\left(\mathbf{c m}^{\mathbf{3}} / \mathbf{g}\right)$ & $\mathbf{V}_{\text {mic }}\left(\mathbf{c m}^{\mathbf{3}} / \mathbf{g}\right)$ & $\mathbf{V}_{\text {mes }}\left(\mathbf{c m}^{\mathbf{3}} / \mathbf{g}\right)$ & $\mathbf{V}_{\text {mic }} / \mathbf{V}_{\mathbf{T}}$ \\
\hline BM & 40 & 0.12 & 0 & 0.12 & - \\
BM-E & 12 & 0.07 & 0 & 0.07 & - \\
AB & 72 & 0.15 & 0 & 0.15 & - \\
AB-E & 64 & 0.16 & 0 & 0.16 & - \\
ABA-1 & 319 & 0.25 & 0.13 & 0.12 & 0.52 \\
ABA-1-E & 177 & 0.27 & 0.02 & 0.25 & 0.07 \\
ABA-2 & 331 & 0.33 & 0.10 & 0.23 & 0.30 \\
ABA-2-E & 100 & 0.15 & 0.02 & 0.13 & 0.13 \\
AB-NG & 105 & 0.24 & 0 & 0.24 & - \\
AB-NG-E & 87 & 0.25 & 0.02 & 0.23 & 0.08 \\
ABA-NG1 & 258 & 0.25 & 0.10 & 0.15 & 0.40 \\
ABA-NG1-E & 86 & 0.14 & 0.01 & 0.13 & 0.07 \\
ABA-NG2 & 350 & 0.27 & 0.17 & 0.10 & 0.63 \\
ABA-NG2-E & 137 & 0.22 & 0.03 & 0.19 & 0.14 \\
\hline
\end{tabular}

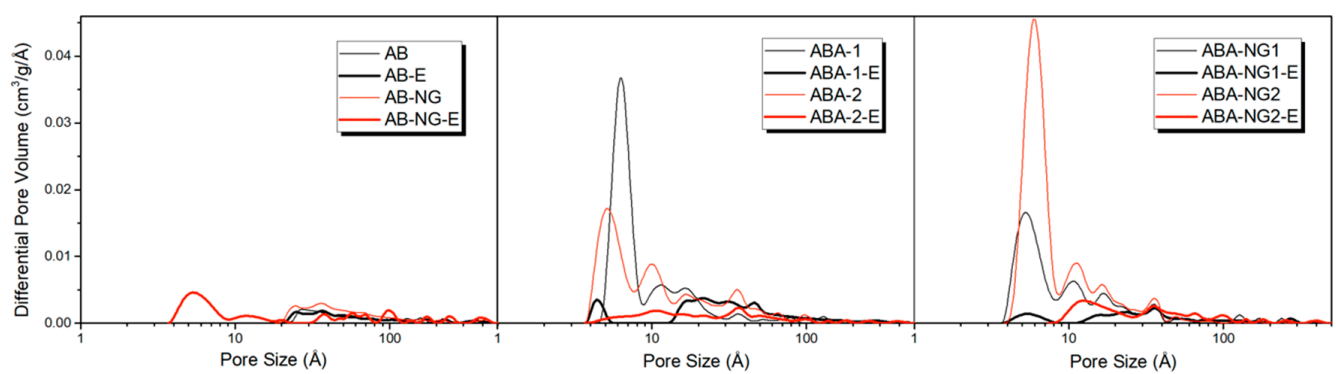

Figure 4. Pore-size distributions for the initial and exhausted samples.

Exposure to $\mathrm{H}_{2} \mathrm{~S}$ significantly decreased the porosity of the samples. This suggests the deposition of the oxidation/reaction products on the surface [45]. The biggest effect is noticed for ABA-NG1 and ABA-2. For these two samples the surface area decreased by $66 \%$ and $70 \%$, respectively. These two carbons also exhibit the highest, and almost identical, performances as $\mathrm{H}_{2} \mathrm{~S}$ adsorbents. These results suggest that even though the addition of NG led to a decrease in the surface area by $22 \%$ relative to ABA-2, it provided surface feature(s) which apparently resulted in the same performance as that of ABA-2. The trend in the decrease in the surface area for the activated samples is consistent with the trend in the $\mathrm{H}_{2} \mathrm{~S}$ breakthrough capacity.

The pore-size distributions (Figure 4) show that $\mathrm{AB}$ and $\mathrm{AB}-\mathrm{NG}$ are predominantly mesoporous. The distribution for $\mathrm{BM}$ was not calculated owing to the nonporous nature of this sample. The activation with $\mathrm{ZnCl}_{2}$ introduced some degree of microporosity to the materials, and it appears that this development of micropores in large part is responsible for the superior performance of the activated samples in the $\mathrm{H}_{2} \mathrm{~S}$ adsorption process. After exposure to $\mathrm{H}_{2} \mathrm{~S}$, the micropores almost disappeared. A similar effect was noticed for the catalytic carbon Midas ${ }^{\circledR}$ [46]. This suggests that micropores are either filled by the products of oxidation or their entrances are blocked by these products. The volume of these micropores might be a limiting factor in the $\mathrm{H}_{2} \mathrm{~S}$ removal process on our materials. Though a relationship between the two measured quantities definitely exists, it does not appear that the volume of micropores is directly proportional to the adsorption capacity. The data 
obtained only indicate that micropores favor the $\mathrm{H}_{2} \mathrm{~S}$ adsorption. The $\mathrm{H}_{2} \mathrm{~S}$ molecule has a critical diameter of $3.2 \AA$; therefore, based on the pore-size distributions, a pore restriction is not expected to occur during the $\mathrm{H}_{2} \mathrm{~S}$ adsorption process on our manure-derived carbonaceous adsorbents. ABA-2 and ABA-NG2 still retained some micropore volume after $\mathrm{H}_{2} \mathrm{~S}$ exposure.

Surface chemistry is another important factor that is expected to affect the $\mathrm{H}_{2} \mathrm{~S}$ reactive adsorption. The $\mathrm{pH}$ values listed in Table 1 indicate the predominantly neutral nature of the adsorbents' surfaces. The best-performing samples have $\mathrm{pH}$ values close to 7 . This is above the $\mathrm{pH}$ threshold of 4.5, which was indicated previously as limiting the surface activity for HS-formation, which is followed by its oxidation either to $\mathrm{SO}_{2}$ or elemental sulfur [43]. The former is promoted when small pores are present and sulfur radicals, spatially separated in them, undergo oxidation to $\mathrm{SO}_{2}$ [46]. As a result of the $\mathrm{H}_{2} \mathrm{~S}$ reactive adsorption, the surface $\mathrm{pH}$ values drop. The largest decrease/acidification is found for ABA-NG1 (3.3 units). Interestingly, on ABA-2, which exhibited the same $\mathrm{H}_{2} \mathrm{~S}$ removal capacity as that of ABA-NG1, the $\mathrm{pH}$ dropped only about 1.5 units. This suggests the differences in the reactive adsorption mechanisms.

The surface species, which are mainly responsible for the average surface $\mathrm{pH}$ of our adsorbents are those present in an inorganic matter. As shown in Table 1, the inorganic matter consists of 55-82 $\mathrm{wt} \%$ the biochar-derived adsorbents. The best-performing samples have around $65 \%$ of inorganic matter. This suggests that the hypothetically separated carbon phase, assuming that the porosity originates only from this phase, would have a surface area of about 1000 and $750 \mathrm{~m}^{2} / \mathrm{g}$ for ABA-2 and ABA-NG1, respectively. This calculation once again indicates that the latter sample is more active despite its lower surface area.

The results of the ICP (Inductively Coupled Plasma) analysis of the inorganic matter are summarized in Table 3. Only $\mathrm{AB}$ and the two best-performing samples were tested. The results for all three samples are very similar and the addition of $10 \% \mathrm{NG}$ or $\mathrm{ZnCl}_{2}$ activation did not significantly change the inorganic phase. In activated samples, slightly more $\mathrm{Zn}$ is present as a leftover after the activation process. The inorganic phase contains marked amounts of $\mathrm{Ca}, \mathrm{Mg}$ and $\mathrm{Fe}$ compounds. While the oxides of the two former compounds were identified previously as catalytic phases promoting $\mathrm{H}_{2} \mathrm{~S}$ dissociation prior to its oxidation to sulfur [34,46,47], iron contributes to the oxidation of sulfur via redox reactions [48]. The same composition of inorganic phases can certainly contribute to the same capacities of ABA-2 and ABA-NG1, but certainly it is not a sufficient condition, since the capacity of $A B$ is much lower. Since $A B$ has a much greater inorganic phase than the other two, the quantity of an inorganic matter does not seem to be the factor determining the adsorption behavior. These results suggest that the porosity of the carbon phase has a dominant role. Even though the surface area of ABA-2 is higher than that of ABA-NG1, their volumes of micropores are very similar and this quantity can be a limiting factor, assuming that the inorganic phase provides sufficient catalytic activity. The analysis of the pore size distributions after $\mathrm{H}_{2} \mathrm{~S}$ adsorption show clear pore blocking, and as a result, the pores are inaccessible almost to the same extent in ABA-2 and ABA-NG1 as a result of reactive adsorption process. The adsorption seems to cease when micropores become occupied or blocked. It is important to mention that in all cases the change in the porosity indicates the deposition of some $\mathrm{H}_{2} \mathrm{~S}$ oxidation products in the pore system. They could be either sulfuric acid, elemental sulfur or sulfur salts [49].

The products of $\mathrm{H}_{2} \mathrm{~S}$ reactive adsorption present in the pore system were analyzed by thermal analysis/mass spectrometry performed in an inert atmosphere. The TG (thermogravimetric) and corresponding DTG (differential thermogravimetric) curves are collected in Figure 5. The peaks on the DTG curves represent the removal of the specific species from the surface. Since the samples were synthesized at $900{ }^{\circ} \mathrm{C}$, all changes observed at temperatures below that should be linked to $\mathrm{H}_{2} \mathrm{~S}$ exposure. For the exhausted AB and AB-NG, the new weight loss appears at 200, 400 and about $600{ }^{\circ} \mathrm{C}$. Based on the history of the samples, the decomposition temperature and the results published in the literature [45,49], we assign those peaks to the removal of sulfuric acid, elemental sulfur and $\mathrm{SO}_{3}$ from the decomposition of iron sulfate, respectively [50]. The peak related to the removal of elemental sulfur 
from BA at $400{ }^{\circ} \mathrm{C}$ is very sharp, which indicates the deposition of a rather small amount of sulfur on the external surface of this low porosity sample. On both BA and BA-NG, the $\mathrm{pH}$ decrease was noticed in spite of the small adsorbed amounts, which supports the formation of sulfuric acid. Interestingly, upon the addition of NG, less elemental sulfur is formed and more sulfur is oxidized to sulfuric acid, which might be linked to the higher volume of small pores. They were found to promote the oxidation of $\mathrm{H}_{2} \mathrm{~S}$ to $\mathrm{SO}_{2}$ and $\mathrm{SO}_{3}$ [51].

Table 3. Chemical composition of ash in $\mathrm{AB}$ and in the best performing samples: ABA-2 and ABA-NG1 (in wt \%).

\begin{tabular}{cccc}
\hline Sample & AB & ABA-2 & ABA-NG1 \\
\hline $\mathrm{Al}_{2} \mathrm{O}_{3}$ & 2.67 & 2.96 & 2.88 \\
$\mathrm{CaO}$ & 58.90 & 57.96 & 56.77 \\
$\mathrm{CuO}$ & 0.81 & 1.047 & 1.21 \\
$\mathrm{Fe}_{2} \mathrm{O}_{3}$ & 5.34 & 5.87 & 6.86 \\
$\mathrm{~K}_{2} \mathrm{O}$ & 1.35 & 0.24 & 0.27 \\
$\mathrm{MgO}$ & 16.90 & 16.47 & 15.36 \\
$\mathrm{MnO}_{2}$ & 0.68 & 0.59 & 0.62 \\
$\mathrm{Na}_{2} \mathrm{O}$ & 0.92 & 0.54 & 0.46 \\
$\mathrm{SiO}_{2}$ & 11.71 & 12.48 & 13.54 \\
$\mathrm{ZnO}$ & 0.33 & 1.52 & 1.66 \\
\hline
\end{tabular}

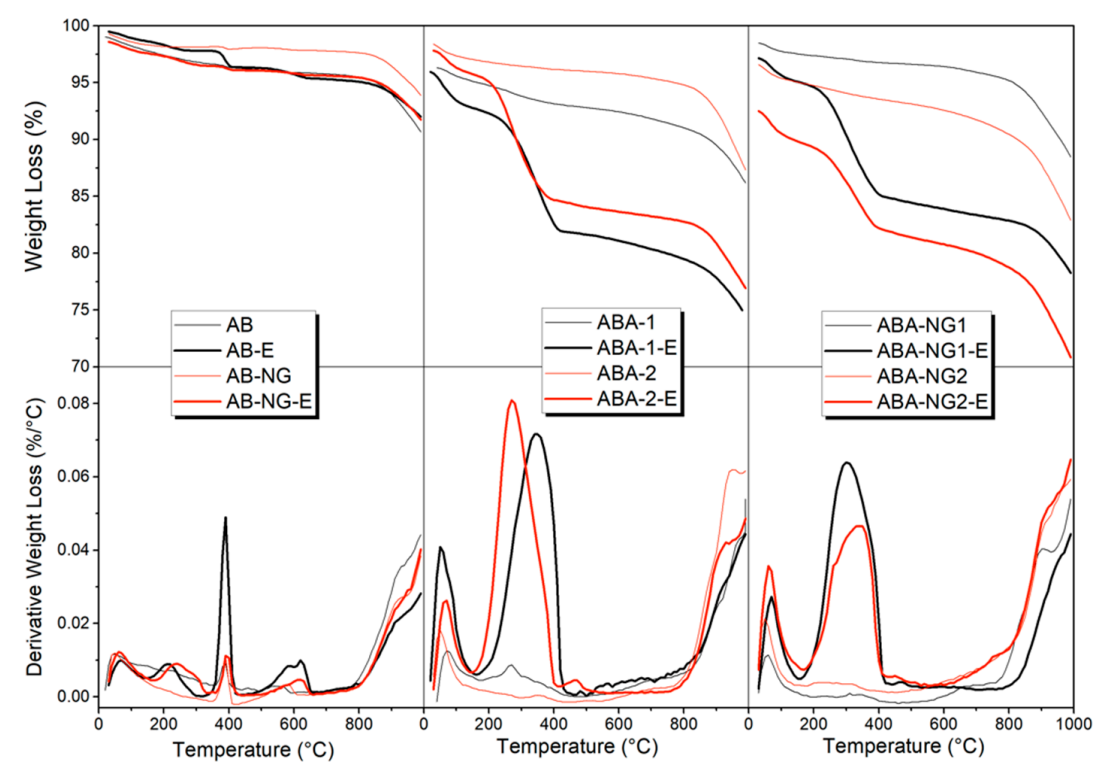

Figure 5. TG (top) and DTG (bottom) curves for initial and exhausted samples.

The weight-loss pattern for all activated samples, regardless of the presence of NG are very similar. The weight loss at about $120{ }^{\circ} \mathrm{C}$ is related to the removal of water and physically adsorbed $\mathrm{H}_{2} \mathrm{~S} / \mathrm{SO}_{2}$. A broad peak between 200 and $400{ }^{\circ} \mathrm{C}$ (centered between 280 and $380{ }^{\circ} \mathrm{C}$, depending on the sample) mainly represents the removal of elemental sulfur, although the removal of sulfuric acid close to $200^{\circ} \mathrm{C}$ can also contribute to it [45]. However, the amount of the latter is rather small. A shift of the peak maximum for ABA- 1 to the higher temperature compared to that for ABA-2 might be related to the smaller pores present in the former sample. In such a system, the removal of sulfur from them requires more energy. The formation of elemental sulfur as a product of reactive adsorption is more desired than that of sulfuric acid. The latter results in the classification of waste as hazardous when the surface $\mathrm{pH}$ decreases to less than 2.

To analyze the products of reactive adsorption in more detail, the high-resolution TA/MS analysis with the heating rate $2{ }^{\circ} \mathrm{C} / \mathrm{min}$ was carried out on ABA-2 and ABA-NG1, initial and exhausted, which showed the best performance in $\mathrm{H}_{2} \mathrm{~S}$ removal. The collected $m / z$ thermal profiles for 18 , 
32 and $64 \mathrm{~m} / \mathrm{z}$ are collected in Figure 6 . They represent water, sulfur and sulfur dioxide, respectively. The trends in the 18 and $64 \mathrm{~m} / z$ can be directly linked to the removal of $\mathrm{H}_{2} \mathrm{SO}_{4}$. Indeed, as suggested above, the most intense peaks on these thermal profiles appear with maximum at about $250{ }^{\circ} \mathrm{C}$ and represent $\mathrm{H}_{2} \mathrm{SO}_{4}$, and then at the higher temperatures mainly sulfur is removed, which consists of the majority of the oxidation products.

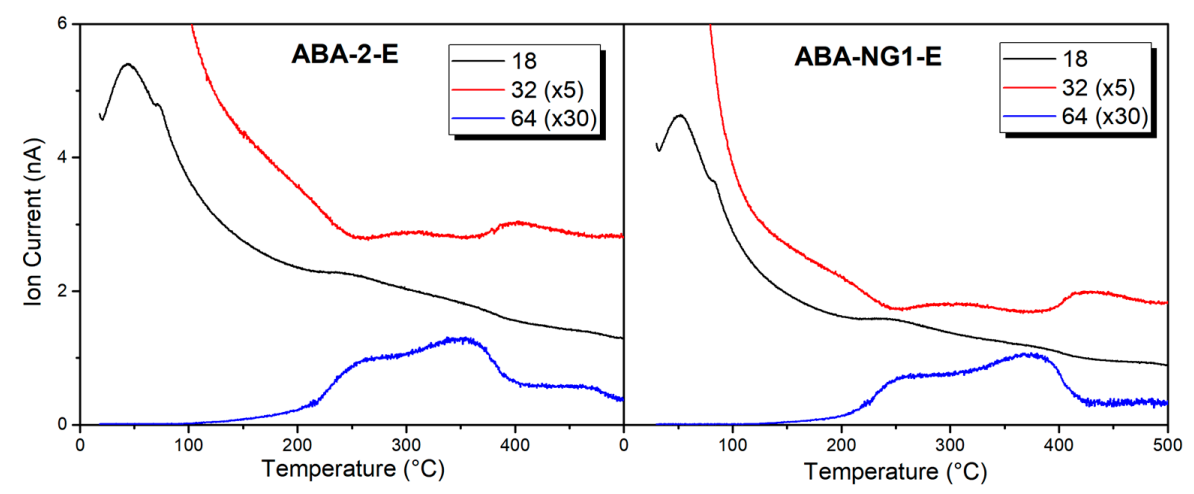

Figure 6. $m / z$ thermal profiles for the best performing samples.

The quantitative analysis of the weight loss can be a confirmation of the $\mathrm{H}_{2} \mathrm{~S}$ reactive adsorption mechanism. The weight losses represented by the main peak for ABA-1-E, ABA-2-E, ABA-NG1-E and ABA-NG2-E are $10 \%, 10 \%, 7 \%$ and $9 \%$, respectively. Based on the $\mathrm{H}_{2} \mathrm{~S}$ breakthrough capacity, assuming that all $\mathrm{H}_{2} \mathrm{~S}$ is converted to sulfur, the weight gain would be expected to be about $13 \%, 14 \%$, $14 \%$ and $12 \%$, respectively. Even though some $\mathrm{SO}_{2} / \mathrm{H}_{2} \mathrm{SO}_{4}$ must be formed based on the broadness of the peak and observed $\mathrm{pH}$ changes, it is in rather a small quantity and mostly reacted with inorganic matter from sulfates. Another reason for the discrepancy in the balance of sulfur is the formation of sulfides, as a result of a direct reaction of $\mathrm{H}_{2} \mathrm{~S}$ with an inorganic matter. $\mathrm{CaS}$ and $\mathrm{MgS}$ are expected to decompose at temperatures higher than $1000{ }^{\circ} \mathrm{C}$ [52]. The results obtained indicate that elemental sulfur is a predominant product of surface reactions on our materials.

The mechanisms of $\mathrm{H}_{2} \mathrm{~S}$ reactive adsorption can be summarized by the following reaction pathways:

$$
\begin{gathered}
\mathrm{H}_{2} \mathrm{~S} \longrightarrow \mathrm{HS}^{-}+\mathrm{H}^{+} \\
2 \mathrm{HS}^{-}+0.5 \mathrm{O}_{2} \rightarrow 2 \mathrm{~S}+\mathrm{H}_{2} \mathrm{O} \\
\mathrm{S}+\mathrm{O}_{2} \rightarrow \mathrm{SO}_{2} \rightarrow \mathrm{SO}_{3} \\
\mathrm{SO}_{3}+\mathrm{H}_{2} \mathrm{O} \rightarrow \mathrm{H}_{2} \mathrm{SO}_{4} \\
\mathrm{CaO}+\mathrm{H}_{2} \mathrm{~S} \rightarrow \mathrm{CaS}+\mathrm{H}_{2} \mathrm{O} \\
\mathrm{MgO}+\mathrm{H}_{2} \mathrm{~S} \rightarrow \mathrm{MgS}+\mathrm{H}_{2} \mathrm{O}
\end{gathered}
$$

The basic environment promotes the dissociation of hydrogen sulfide in the film of water and then HS-ions are oxidized either to sulfur, sulfur polymers or sulfur oxides, depending on their location in the pore system. Small isolated pores promote the formation of $\mathrm{SO}_{3}$ and sulfuric acid [43]. Some $\mathrm{H}_{2} \mathrm{~S}$ is also expected to react with alkali earth metal oxides/salts forming sulfides.

Based on the chemistry and porosity, the mechanism of air desulfurization follows that on catalytic carbon Midas ${ }^{\circledR}$ [46]. That catalyst has the surface area of $1100 \mathrm{~m}^{2} / \mathrm{g}$ and $30 \%$ of calcium/magnesium oxides. The surface area of our materials and thus their pore volume is about 3-4 times less than that of Midas ${ }^{\circledR}$. The $\mathrm{H}_{2} \mathrm{~S}$ removal activity per unit surface area is $0.41,0.43,0.55$ and $0.36 \mathrm{mg} / \mathrm{m}^{2}$ for ABA- 1 , ABA-2, ABA-NG1 and ABNG-2, respectively. Interestingly, for ABA-NG1 the value is similar to that on Midas ${ }^{\circledR}\left(0.6 \mathrm{mg} / \mathrm{m}^{2}\right)$. It is important to mention that so far Midas ${ }^{\circledR}$ has been identified as the most 
efficient catalyst for oxidation of $\mathrm{H}_{2} \mathrm{~S}$ from air. It is able to convert it to elemental sulfur and retains $60 \%$ of its weight in the pore system [53].

As indicated in our objectives we have added NG not only to increase the content of the carbon phase but also to increase the conductivity and thus the efficiency of an electron transfer, which is important for redox reactions governing $\mathrm{H}_{2} \mathrm{~S}$ oxidation on the surface [54]. Indeed, the sheet resistance of the activated samples were $25,43,14$ and $19 \Omega$ for ABA-1, ABA-2, ABA-NG1 and ABA-NG2, respectively, as measured for their thin films on the gold chips. Since indeed an increase in conductivity was found upon the addition of NG, this, in conjunction with the other favorable features discussed above, can be the reason for ABA-NG1 effectiveness being close to that of Midas ${ }^{\circledR}$ carbon.

XRD analyses were conducted on the initial and exhausted materials, however they did not provide more details to further explain the superior performance of the activated samples as $\mathrm{H}_{2} \mathrm{~S}$ adsorbents. The crystal structure of the exhausted samples remained unchanged in comparison to the initial one. This in fact supports the finding that the oxidation product is amorphous sulfur deposited in the pore system and formed sulfates/sulfides are either in the amorphous form or deposited as very small particles not detectable by XRD.

\section{Materials and Methods}

\subsection{Materials}

Pig-manure-derived char (BM), was recovered as a waste after a $280{ }^{\circ} \mathrm{C}$ hydrothermal treatment process $[55,56]$. This initial sample $(\mathrm{BM})$ was subjected to various treatments including pyrolysis and chemical activation. Reagent grade $\mathrm{ZnCl}_{2}(>98 \%$ Aldrich, St. Louis, $\mathrm{MO}, \mathrm{USA})$ was used for the chemical activation and nanographite (NG) (Nano 24-Asbury Graphite Mills, Inc., Asbury, NJ, USA) was used to increase the conductivity and the carbon phase content of the composites.

\subsection{Synthesis of the Composites}

Pyrolysis of the BM was carried out in a horizontal furnace. A $3 \mathrm{~g}$ sample was placed into a crucible and heated to $900{ }^{\circ} \mathrm{C}$ at $10{ }^{\circ} \mathrm{C} / \mathrm{min}$ in a $\mathrm{N}_{2}$ atmosphere. The maximum temperature was held for one hour and then the sample was allowed to cool down to room temperature under a nitrogen flow. The synthesized material is referred to as AB.

For the zinc chloride $\left(\mathrm{ZnCl}_{2}\right)$ chemical activation, $7 \mathrm{~g}$ of the $\mathrm{M}$ sample were dispersed in $15 \mathrm{~mL}$ of either 3.4 $\mathrm{M} \mathrm{ZnCl}_{2}$ or $6.8 \mathrm{M} \mathrm{ZnCl}_{2}$. The carbon to $\mathrm{ZnCl}_{2}$ ratio was either 1:1 or 1:2. The solution was stirred at $80^{\circ} \mathrm{C}$ for about $15 \mathrm{~min}$ and then the remaining slurry was dried overnight at $120^{\circ} \mathrm{C}$. The dry solid was pyrolized at $900{ }^{\circ} \mathrm{C}$ at the same conditions at which sample $\mathrm{AB}$ was obtained. After pyrolysis, the sample was washed in a Soxhlet apparatus to remove all residual impurities and until a stable $\mathrm{pH}$ was reached and a test for chloride ions was negative. The washed sample was then dried at $100{ }^{\circ} \mathrm{C}$ and referred to as ABA- 1 and ABA-2 for $1: 1$ and 1:2 ratios, respectively.

Composites with nanographite were prepared by mixing the BM sample with nanographite, NG. The amount of the latter was $10 \%(w / w)$ of the raw material $(\mathrm{BM})$. The samples were dispersed in water and the solution was stirred at $80^{\circ} \mathrm{C}$ for about $15 \mathrm{~min}$. Then the remaining slurry was dried overnight at $120^{\circ} \mathrm{C}$. The dry solid was then pyrolized at $900^{\circ} \mathrm{C}$. This sample was referred to as AB-NG. As a next step, it was activated with $\mathrm{ZnCl}_{2}$ following the same procedure as that for the ABA- 1 and ABA-2 samples. The activated composites are referred to as ABA-NG1 and ABA-NG2, where the digits 1 and 2 represent the ratio of the dry precursor mixtures to $\mathrm{ZnCl}_{2}$, respectively. The samples exposed to $\mathrm{H}_{2} \mathrm{~S}$ in the dynamic test are referred to with the suffix ' $\mathrm{E}$ '. 


\subsection{Methods}

\subsection{1. $\mathrm{H}_{2} \mathrm{~S}$ Breakthrough Capacity}

Adsorbent samples of a size between 0.4 and $0.6 \mathrm{~mm}$ were packed into a glass column (length: $370 \mathrm{~mm}$; internal diameter: $9 \mathrm{~mm}$ ) with a bed volume of $3.0 \mathrm{~cm}^{3}$. The $\mathrm{H}_{2} \mathrm{~S}$ adsorption tests were carried out in moist conditions. Before the $\mathrm{H}_{2} \mathrm{~S}$ test, the samples were pre-humidified with moist air (70\% relative humidity at $25^{\circ} \mathrm{C}$ ) for two hours. The humid air containing $0.1 \%(1000 \mathrm{ppm}) \mathrm{H}_{2} \mathrm{~S}$ was passed through a column of the adsorbent at a total flow rate of $500 \mathrm{~mL} / \mathrm{min}$. The $\mathrm{H}_{2} \mathrm{~S}$ concentration was monitored from the outlet gas of the column by using a RAE MultiRae Plus monitoring system (RAE Systems, Inc., San Jose, CA, USA) with an electrochemical sensor. $\mathrm{The}_{2} \mathrm{~S}$ breakthrough curves were measured within the range of $0-100 \mathrm{ppm}$ (100 ppm is the sensor limit). The amount of $\mathrm{H}_{2} \mathrm{~S}$ adsorbed was calculated by the integration of the area above the breakthrough curves taking into account the mass of the sample, flow rate, concentration of $\mathrm{H}_{2} \mathrm{~S}$ and time. Additionally, the sulfur dioxide $\left(\mathrm{SO}_{2}\right)$ concentration as a possible $\mathrm{H}_{2} \mathrm{~S}$ reaction byproduct, which might be released from the surface of the adsorbents, was recorded.

\subsubsection{Evaluation of Porosity}

Nitrogen adsorption isotherms were measured at $-196^{\circ} \mathrm{C}$, using a ASAP 2020 (Micromeritics, Norcross, GA, USA) surface area and porosity analyzer. Prior to each measurement, initial samples were outgassed at $120^{\circ} \mathrm{C}$ to vacuum $10^{-4}$ Torr. The surface area $\left(\mathrm{S}_{\mathrm{BET}}\right)$ and porosity of the samples were calculated from the measured isotherms. The volumes of pore and the pore-size distributions were calculated using the density functional theory (NLDFT) method based on heterogeneous pore sizes [57].

\subsubsection{X-ray Diffraction (XRD)}

The XRD measurements were obtained using a Phillips X'Pert X-ray diffractometer (PANalytical, Almelo, The Netherlands). The adsorbent was ground into a fine powder and analyzed by $\mathrm{CuK}_{\alpha}$ radiation at $40 \mathrm{kV}$ and $40 \mathrm{~mA}$.

\subsubsection{Measurements of Electrical Resistance}

A film of a sample dispersed $N$-methyl-2-pyrrolidone (NMP) was coated on a $0.5 \mathrm{~cm} \times 0.45 \mathrm{~cm}$ gold interdigitated electrode. The samples were dried at $120^{\circ} \mathrm{C}$ for $24 \mathrm{~h}$ to evaporate the NMP solvent. The sheet resistance was measured with a four-probe method using Keithley 2400 Multimeter (Keithley Instruments, Cleveland, OH, USA).

\subsubsection{Thermal Analysis}

Thermogravimetric (TG) curves were obtained using a SDT Q600 Simultaneous TGA/DSC Thermal Analyzer (TA Instruments, Newcastle, DE, USA). About $25 \mathrm{mg}$ (of the initial and exhausted samples) were exposed to a heating rate of $10^{\circ} \mathrm{C} / \mathrm{min}$ up to $900{ }^{\circ} \mathrm{C}$ under a constant helium (He) flow of $100 \mathrm{~mL} / \mathrm{min}$. The differential thermogravimetric (DTG) curves were derived from the thermogravimetric (TG) curves. The high-resolution tests were performed in helium with a heating rate of $2{ }^{\circ} \mathrm{C} / \mathrm{min}$. Simultaneously, the $m / z$ thermal profiles were recorded on a gas analysis system Omnistar GSD 320 (Pfeiffer Vacuum, Annecy, France).

\section{Conclusions}

The results obtained suggest that newly-developed biochar from pig manure liquefaction can be used as a source of catalytic adsorbents for hydrogen sulfide removal from air. The catalytic sites and developed porosity are needed to ensure good adsorption performance. It was achieved here by the $\mathrm{ZnCl}_{2}$ activation. The $\mathrm{H}_{2} \mathrm{~S}$ removal capacity for our newly-developed, biochar-based reactive 
adsorbents was high and comparable to that of high surface-area, catalytic-activated carbons. The most active was the surface of the composite with 10\% of NG and 1:1 activation agent ratio. The presence of high amounts of calcium and magnesium in pig manure along with the pores in the carbons phase is responsible for the good performance of ABA-NG1. The nanographite phase, although in a small quantity and not significantly affecting the surface features, increased the content of the carbon phase and thus the conductivity, which plays a role in redox reactions. The relatively small volume of micropores is identified as a factor limiting the performance. This suggests that by the addition of a porous carbon phase to pig manure, an upgrade in the performance is likely to be achieved for air desulfurization. Owing to the catalytic properties, there is no direct relationship between the overall porosity and the amount of $\mathrm{H}_{2} \mathrm{~S}$ adsorbed. Oxidation to elemental sulfur is a desirable feature from the point of view of the spent adsorbent disposal and regeneration. The results suggest that by thermal treatment up to $400{ }^{\circ} \mathrm{C}$, the adsorbents can be partially regenerated. This is owing to elemental sulfur being the major product of $\mathrm{H}_{2} \mathrm{~S}$ reactive adsorption

Acknowledgments: Sundaramurthy Suresh is grateful to SERB Indo-US Postdoctoral Fellowship. The authors thank Albert Tamashausky of Asbury Carbon for nanographite sample and for help with ICP analysis. Experimental help of Karifala Kante is appreciated. The partnership between CCNY and North Carolina A \& T was enabled by the National Science Foundation (Awards Nos.: 1150695 \& 1546921).

Author Contributions: Rajiv Wallace prepared the experimental set up, helped with the synthesis of the samples, and their characterization, and wrote the paper draft. Sundaramurthy Suresh synthesized the samples, measured the performance, characterized the samples, collected the data, Elham H. Fini developed bio-char using thermochemical processing of pig manure, Teresa J. Bandosz designed the experimental steps, analyzed the data and worked on the final version of the paper.

Conflicts of Interest: The authors declare no conflict of interest.

\section{References}

1. Zhu, J. A review of microbiology in swine manure odor control. Agric. Ecosyst. Environ. 2000, 78, 93-106. [CrossRef]

2. Sharpley, A.; Meisinger, J.J.; Breeuwsma, A.; Sims, J.T.; Daniel, T.C.; Schepers, J.S. Impacts of animal manure management on ground and surface water quality. In Anim. Waste Util; CRC Press: Boca Raton, FL, USA, 1998; pp. 173-242. [CrossRef]

3. Reiffenstein, R.J.; Hulbert, W.C.; Roth, S.H. Toxicology of Hydrogen Sulfide. Annu. Rev. Pharmacol. Toxicol. 1992, 32, 109-134. [CrossRef] [PubMed]

4. Beauchamp, R.O.; Bus, J.S.; Popp, J.A.; Boreiko, C.J.; Andjelkovich, D.A.; Leber, P. A Critical Review of the Literature on Hydrogen Sulfide Toxicity. CRC Crit. Rev. Toxicol. 1984, 13, 25-97. [CrossRef] [PubMed]

5. Legator, M.S.; Morris, D.L.; Philips, D.L.; Singleton, C.R. Health Effects from Chronic Low-Level Exposure to Hydrogen Sulfide. Arch. Environ. Health 2001, 56, 123-131. [CrossRef] [PubMed]

6. Adib, F.; Bagreev, A.; Bandosz, T. Effect of Surface Characteristics of Wood-Based Activated Carbons on Adsorption of Hydrogen Sulfide. J. Colloid Interface Sci. 1999, 214, 407-415. [CrossRef] [PubMed]

7. Le Leuch, L.M.; Subrenat, A.; Le Cloirec, P. Hydrogen sulfide adsorption and oxidation onto activated carbon cloths: Applications to odorous gaseous emission treatments. Langmuir 2003, 19, 10869-10877. [CrossRef]

8. Bagreev, A.; Rahman, H.; Bandosz, T.J. Wood-Based Activated Carbons as Adsorbents of Hydrogen Sulfide: A Study of Adsorption and Water Regeneration Processes. Ind. Eng. Chem. Res. 2000, 39, 3849-3855. [CrossRef]

9. Bandosz, T.J.; Le, Q. Evaluation of surface properties of exhausted carbons used as $\mathrm{H}_{2} \mathrm{~S}$ adsorbents in sewage treatment plants. Carbon 1998, 36, 39-44. [CrossRef]

10. Xu, X.; Cao, X.; Zhao, L.; Sun, T. Comparison of sewage sludge- and pig manure-derived biochars for hydrogen sulfide removal. Chemosphere 2014, 111, 296-303. [CrossRef] [PubMed]

11. Azargohar, R.; Dalai, A.K. The direct oxidation of hydrogen sulphide over activated carbons prepared from lignite coal and biochar. Can. J. Chem. Eng. 2011, 89, 844-853. [CrossRef]

12. Kizito, S.; Wu, S.; Kipkemoi Kirui, W.; Lei, M.; Lu, Q.; Bah, H.; Dong, R. Evaluation of slow pyrolyzed wood and rice husks biochar for adsorption of ammonium nitrogen from piggery manure anaerobic digestate slurry. Sci. Total Environ. 2015, 505, 102-112. [CrossRef] [PubMed] 
13. Zielinska, A.; Oleszczuk, P. Evaluation of sewage sludge and slow pyrolyzed sewage sludge-derived biochar for adsorption of phenanthrene and pyrene. Bioresour. Technol. 2015, 192, 618-626. [CrossRef] [PubMed]

14. Kearns, J.P.; Wellborn, L.S.; Summers, R.S.; Knappe, D.R.U. 2,4-D adsorption to biochars: Effect of preparation conditions on equilibrium adsorption capacity and comparison with commercial activated carbon literature data. Water Res. 2014, 62, 20-28. [CrossRef] [PubMed]

15. Kiliç, M.; Kirbiyik, Ç.; Çepelioğullar, Ö.; Pütün, A.E. Adsorption of heavy metal ions from aqueous solutions by bio-char, a by-product of pyrolysis. Appl. Surf. Sci. 2013, 283, 856-862. [CrossRef]

16. Xue, Y.; Gao, B.; Yao, Y.; Inyang, M.; Zhang, M.; Zimmerman, A.R.; Rod, K.S. Hydrogen peroxide modification enhances the ability of biochar (hydrochar) produced from hydrothermal carbonization of peanut hull to remove aqueous heavy metals: Batch and column tests. Chem. Eng. J. 2012, 200-202, 673-680. [CrossRef]

17. Adinata, D.; Wan Daud, W.M.A.; Aroua, M.K. Preparation and characterization of activated carbon from palm shell by chemical activation with $\mathrm{K}_{2} \mathrm{CO}_{3}$. Bioresour. Technol. 2007, 98, 145-149. [CrossRef] [PubMed]

18. Karagöz, S.; Tay, T.; Ucar, S.; Erdem, M. Activated carbons from waste biomass by sulfuric acid activation and their use on methylene blue adsorption. Bioresour. Technol. 2008, 99, 6214-6222. [CrossRef] [PubMed]

19. Prahas, D.; Kartika, Y.; Indraswati, N.; Ismadji, S. Activated carbon from jackfruit peel waste by $\mathrm{H}_{3} \mathrm{PO}_{4}$ chemical activation: Pore structure and surface chemistry characterization. Chem. Eng. J. 2008, 140, 32-42. [CrossRef]

20. Begreev, A.; Locke, D.C.; Bandosz, T.J. $\mathrm{H}_{2} \mathrm{~S}$ adsorption/oxidation on adsorbents obtained from pyrolysis of sewage sludge-derived fertilizer using zinc chloride activation. Ind. Eng. Chem. Res. 2001, 40, 3502-3510. [CrossRef]

21. Jeyaseelan, S.; Qing, L.G. Development of adsorbent/catalyst from municipal wastewater sludge. Water Sci. Technol. 1996, 34, 499-505. [CrossRef]

22. Fan, Y.; Zhang, F.S.; Feng, Y. An effective adsorbent developed from municipal solid waste and coal co-combustion ash for As(V) removal from aqueous solution. J. Hazard. Mater. 2008, 159, 313-318. [CrossRef] [PubMed]

23. Bandosz, T.J.; Block, K. Municipal sludge-industrial sludge composite desulfurization adsorbents: Synergy enhancing the catalytic properties. Environ. Sci. Technol. 2006, 40, 3378-3383. [CrossRef] [PubMed]

24. Jain, A.K.; Gupta, V.K.; Bhatnagar, A.; Suhas. Utilization of industrial waste products as adsorbents for the removal of dyes. J. Hazard. Mater. 2003, 101, 31-42. [CrossRef]

25. Bhatnagar, A.; Jain, A.K. A comparative adsorption study with different industrial wastes as adsorbents for the removal of cationic dyes from water. J. Colloid Interface Sci. 2005, 281, 49-55. [CrossRef] [PubMed]

26. Ahmaruzzaman, M. Industrial wastes as low-cost potential adsorbents for the treatment of wastewater laden with heavy metals. Adv. Colloid Interface Sci. 2011, 166, 36-59. [CrossRef] [PubMed]

27. Tsai, W.-T.; Chen, H.-R. Adsorption kinetics of herbicide paraquat in aqueous solution onto a low-cost adsorbent, swine-manure-derived biochar. Int. J. Environ. Sci. Technol. 2013, 10, 1349-1356. [CrossRef]

28. Mohan, D.; Sarswat, A.; Ok, Y.S.; Pittman, C.U. Organic and inorganic contaminants removal from water with biochar, a renewable, low cost and sustainable adsorbent-A critical review. Bioresour. Technol. 2014, 160, 191-202. [CrossRef] [PubMed]

29. Meng, J.; Feng, X.; Dai, Z.; Liu, X.; Wu, J.; Xu, J. Adsorption characteristics of Cu(II) from aqueous solution onto biochar derived from swine manure. Environ. Sci. Pollut. Res. 2014, 21, 7035-7046. [CrossRef] [PubMed]

30. Ros, A.; Lillo-Ródenas, M.A.; Fuente, E.; Montes-Morán, M.A.; Martín, M.J.; Linares-Solano, A. High surface area materials prepared from sewage sludge-based precursors. Chemosphere 2006, 65, 132-140. [CrossRef] [PubMed]

31. Wallace, R.; Seredych, M.; Zhang, P.; Bandosz, T.J. Municipal waste conversion to hydrogen sulfide adsorbents: Investigation of the synergistic effects of sewage sludge/fish waste mixture. Chem. Eng. J. 2014, 237, 88-94. [CrossRef]

32. Zhang, F.-S.; Nriagu, J.O.; Itoh, H. Mercury removal from water using activated carbons derived from organic sewage sludge. Water Res. 2005, 39, 389-395. [CrossRef] [PubMed]

33. Martin, M.J.; Balaguer, M.D.; Rigolak, M. Feasibility of activated carbon production from biological sludge by chemical activation with $\mathrm{ZnCl}_{2}$ and $\mathrm{H}_{2} \mathrm{SO}_{4}$. Environ. Technol. 1996, 17, 667-671. [CrossRef]

34. Bagreev, A.; Bashkova, S.; Locke, D.G.; Bandosz, T.J. Sewage sludge-derived materials as efficient adsorbents for removal of hydrogen sulfide. Environ. Sci. Technol. 2001, 35, 1537-1543. [CrossRef] [PubMed]

35. Beesley, L.; Dickinson, N. Carbon and trace element fluxes in the pore water of an urban soil following greenwaste compost, woody and biochar amendments, inoculated with the earthworm Lumbricus terrestris. Soil Biol. Biochem. 2011, 43, 188-196. [CrossRef] 
36. Chen, X.; Chen, G.; Chen, L.; Chen, Y.; Lehmann, J.; McBride, M.B.; Hay, A.G. Adsorption of copper and zinc by biochars produced from pyrolysis of hardwood and corn straw in aqueous solution. Bioresour. Technol. 2011, 102, 8877-8884. [CrossRef] [PubMed]

37. Yuan, J.H.; Xu, R.K.; Zhang, H. The forms of alkalis in the biochar produced from crop residues at different temperatures. Bioresour. Technol. 2011, 102, 3488-3497. [CrossRef] [PubMed]

38. Lima, I.; Marshall, W.E. Utilization of turkey manure as granular activated carbon: Physical, chemical and adsorptive properties. Waste Manag. 2005, 25, 726-732. [CrossRef] [PubMed]

39. Barrow, C.J. Biochar: Potential for countering land degradation and for improving agriculture. Appl. Geogr. 2012, 34, 21-28. [CrossRef]

40. Lehmann, J.; Joseph, S. Biochar for environmental management: An introduction. In Biochar for Environmental Management: Science and Technology; Earthscans: London, UK, 2009; Volume 1, pp. 1-12. [CrossRef]

41. Ahmad, M.; Rajapaksha, A.U.; Lim, J.E.; Zhang, M.; Bolan, N.; Mohan, D.; Vithanage, M.; SooLee, S.; SikOk, Y. Biochar as a sorbent for contaminant management in soil and water: A review. Chemosphere 2014, 99, $19-23$. [CrossRef] [PubMed]

42. Hosseinnezhad, S.H.; Fini, E.H.; Sharma, B.K.; Basti, M.; Kunwar, B. Physiochemical characterization of synthetic bio-oils produced from bio-mass: A sustainable source for construction bio-adhesives. RSC Adv. 2015, 5, 519-527. [CrossRef]

43. Bandosz, T.J. On the adsorption/oxidation of hydrogen sulfide on unmodified activated carbons at ambient temperatures. J. Colloid Interface Sci. 2002, 246, 1-20. [CrossRef] [PubMed]

44. Adib, F.; Bagreev, A.; Bandosz, T.J. Adsorption/oxidation of hydrogen sulfide on nitrogen-containing activated carbons. Langmuir 2000, 16, 1980-1986. [CrossRef]

45. Adib, F.; Bagreev, A.; Bandosz, T.J. Analysis of the relationship between $\mathrm{H}_{2} \mathrm{~S}$ removal capacity and surface properties of unmodified activated carbons. Environ. Sci. Technol. 2000, 34, 686-692. [CrossRef]

46. Bagreev, A.; Bandosz, T.J. On the Mechanism of Hydrogen Sulfide Removal from Moist Air on Catalytic Carbonaceous Adsorbents. Ind. Eng. Chem. Res. 2005, 44, 530-538. [CrossRef]

47. Yan, R.; Liang, D.T.; Tsen, L.; Tay, J.H. Kinetics and mechanisms of $\mathrm{H}_{2} \mathrm{~S}$ adsorption by alkaline activated carbon. Environ. Sci. Technol. 2002, 36, 4460-4466. [CrossRef] [PubMed]

48. Steijns, M.; Derks, F.; Verloop, A.; Mars, P. The mechanism of the catalytic oxidation of hydrogen sulfide. II. Kinetics and mechanism of hydrogen sulfide oxidation catalyzed by sulfur. J. Catal. 1976, 42, 87-95. [CrossRef]

49. Bagreev, A.; Menendez, J.A.; Dukhno, I.; Tarasenko, Y.; Bandosz, T.J. Bituminous coal-based activated carbons modified with nitrogen as adsorbents of hydrogen sulfide. Carbon 2004, 42, 469-476. [CrossRef]

50. Arcibar-Orozco, J.A.; Wallace, R.; Mitchell, J.K.; Bandosz, T.J. Role of surface chemistry and morphology in the reactive adsorption of $\mathrm{H}_{2} \mathrm{~S}$ on Iron (Hydr)oxide/graphite oxide composites. Langmuir 2015, 31, 2730-2742. [CrossRef] [PubMed]

51. Bandosz, T.J. Desulfurization on activated carbons. In Activated Carbon Surfaces in Environmental Remediation; Bandosz, T.J., Ed.; Elsevier: Amsterdam, The Netherlands, 2006; pp. 231-292.

52. Haynes, W. CRC Handbook of Chemistry and Physics, 97th ed.; CRC Press: Boca Raton, FL, USA, 2003.

53. Bandosz, T.J.; Bagreev, A. Carbonaceous materials for gas phase desulfurization: Role of surface heterogeneity. Prepr. Pap. Am. Chem. Soc. Div. Fuel Chem. 2004, 49, 817-821.

54. Seredych, M.; Mabayoje, O.; Koleśnik, M.M.; Krstić, V.; Bandosz, T.J. Zinc (hydr)oxide/graphite based-phase composites: Effect of the carbonaceous phase on surface properties and enhancement in electrical conductivity. J. Mater. Chem. 2012, 22, 7970. [CrossRef]

55. Fini, E.H.; Kalberer, E.W.; Shahbazi, G.; Basti, M.; You, Z.; Ozer, H.; Aurangzeb, Q. Chemical characterization of Biobinder from swine manure: Sustainable modifier for asphalt binder. J. Mater. Civ. Eng. 2012, 23, 1506-1513. [CrossRef]

56. Walters, R.; Begum, S.H.A.; Fini, E.; Abu-Lebdeh, T.M. Investigating bio-char as flow modifier and water treatment agent for sustainable pavement design. Am. J. Eng. Appl. Sci. 2014, 8, 138-146. [CrossRef]

57. Jagiello, J.; Olivier, J.P. Carbon slit pore model incorporating surface energetical heterogeneity and geometrical corrugation. Adsorption 2003, 19, 777-783. [CrossRef]

(C) 2017 by the authors. Licensee MDPI, Basel, Switzerland. This article is an open access article distributed under the terms and conditions of the Creative Commons Attribution (CC BY) license (http:/ / creativecommons.org/licenses/by/4.0/). 